\title{
Tracing population movements in ancient East Asia through the linguistics and archaeology of textile production
}

\author{
Sarah Nelson ${ }^{1}$, Irina Zhushchikhovskaya ${ }^{2}$, Tao $\mathrm{Li}^{3,4}$, Mark Hudson $^{3}$ (D) and Martine Robbeets ${ }^{3 *}$ (D) \\ ${ }^{1}$ Department of Anthropology, University of Denver, Denver, CO, USA, ${ }^{2}$ Laboratory of Medieval Archaeology, Institute of \\ History, Archaeology and Ethnography of Peoples of Far East, Far Eastern Branch of Russian Academy of Sciences, \\ Vladivostok, Russia, ${ }^{3}$ Eurasia3angle Research group, Max Planck Institute for the Science of Human History, Jena, Germany \\ and ${ }^{4}$ Department of Archaeology, Wuhan University, Wuhan, China \\ ${ }^{*}$ Corresponding author. E-mail: robbeets@shh.mpg.de
}

\begin{abstract}
Archaeolinguistics, a field which combines language reconstruction and archaeology as a source of information on human prehistory, has much to offer to deepen our understanding of the Neolithic and Bronze Age in Northeast Asia. So far, integrated comparative analyses of words and tools for textile production are completely lacking for the Northeast Asian Neolithic and Bronze Age. To remedy this situation, here we integrate linguistic and archaeological evidence of textile production, with the aim of shedding light on ancient population movements in Northeast China, the Russian Far East, Korea and Japan. We show that the transition to more sophisticated textile technology in these regions can be associated not only with the adoption of millet agriculture but also with the spread of the languages of the so-called 'Transeurasian' family. In this way, our research provides indirect support for the Language/Farming Dispersal Hypothesis, which posits that language expansion from the Neolithic onwards was often associated with agricultural colonization.
\end{abstract}

Keywords: Archaeolinguistics; Language/Farming Dispersal Hypothesis; Transeurasian language family; textile technology; Northeast Asia

Media summary: Archaeolinguistics, which combines language reconstruction and archaeology as a source of information on human prehistory, has much to offer to deepen our understanding of the Neolithic and Bronze Age in Northeast Asia. Here we integrate the language and archaeology of textile production as a marker of agricultural dispersal and population migration in Northeast China, the Russian Far East, Korea and Japan. We show that the transition to more sophisticated textile technology in these regions can be associated with the adoption of millet agriculture and the spread of the so-called 'Transeurasian' language family. In this way, our research provides indirect support for the Language/Farming Dispersal Hypothesis, which posits that language expansion from the Neolithic onwards was often associated with agricultural colonization.

\section{Introduction}

The Language/Farming Dispersal Hypothesis makes the radical and controversial claim that many of the world's major language families owe their premodern distribution to the adoption of agriculture by their early speakers (Bellwood 1984; Renfrew 1987; Bellwood and Renfrew 2002; Diamond and Bellwood 2003; Bellwood 2005, 2011; Robbeets and Savelyev 2017). The standard technique to test this hypothesis for a given language family is to use reconstructed words with an agricultural meaning

(c) The Author(s) 2020. This is an Open Access article, distributed under the terms of the Creative Commons Attribution licence (http://creative commons.org/licenses/by/4.0/), which permits unrestricted re-use, distribution, and reproduction in any medium, provided the original work is properly cited. 


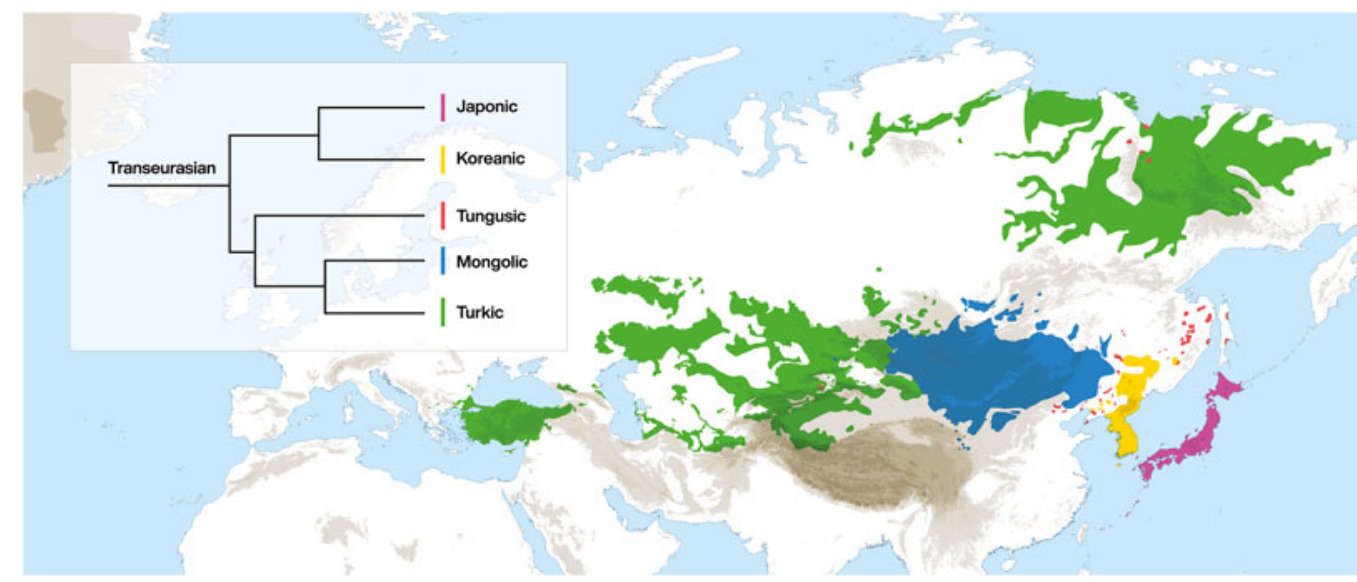

Figure 1. The distribution and classification of the Transeurasian languages.

as a way of determining whether the ancestral speakers were familiar with agriculture. This method has been used to support or reject agriculture-driven language spread for a wide range of language families such as Indo-European (Comrie 2002; Anthony 2007; Kroonen 2012; Iversen and Kroonen 2017; Kümmel 2017), Sino-Tibetan (Sagart et al. 2019), Austronesian (Blust 1995, 2013; Pawley 2002), Austroasiatic (Sidwell and Blench 2011; van Driem 2017), Trans-New Guinean (Schapper 2017), Bantu (Philipson 2002; Bostoen and Koni Muluwa 2017), Arawak (Aikhenvald 1999) and Otomanguean (Kaufman 1990; Brown 2015). Recently, agricultural vocabulary has also been attributed to the ancestor of the Transeurasian languages, supporting the claim that the primary dispersal of these languages was agriculture-driven (Robbeets 2017, 2020a).

The term 'Transeurasian' replaces the traditional label 'Altaic' and refers to the large group of geographically adjacent languages, stretching across Europe and Asia, presented in Figure 1. It includes five uncontroversial linguistic families: Japonic, Koreanic, Tungusic, Mongolic and Turkic. The question of whether these five groups descend from a single common ancestor has been the topic of a longstanding debate (Starostin et al. 2003; Vovin 2005; Dybo and Starostin 2008; Johanson 2010). Recent assessments have shown that even if the historical relationship between the Transeurasian languages is heavily marked by borrowing, there is nonetheless a core of reliable evidence for the classification of Transeurasian as a valid genealogical grouping (Robbeets 2005, 2015, 2020b, c).

Here we will test the claim that Transeurasian language dispersal was initially agriculture-driven by investigating words and material evidence beyond agriculture. The logic behind this approach is that when agriculture drives people to move along with the language they speak, we expect that, besides crops and farming technology, other aspects of material culture will move as well. Given the importance of textile production in the ancient cultures and languages of the Transeurasian-speaking region, we here search for a correlation between the use of agriculture, textile production and the words reflecting these activities. To this end, we will first compare words for textile production across the Transeurasian languages and reconstruct them back to the common ancestral language. These reconstructions will enable us to make predictions about the prehistory of textile production in the Transeurasian-speaking region. We will verify our predictions through a comparative survey of textile technology in Northeast China, the Russian Far East, Korea and Japan in the Neolithic and Bronze Age. Finally, we will compare the distribution of tools and words and map our linguistic inferences on those from archaeology.

While studies on the linguistics of textile production in individual Transeurasian languages are extremely rare (for Japanese, see Omura and Kizawa 2017; for Turkic, Levitskaya 1997a-c; for the borrowing of 'silk' from Sinitic into Mongolic into Turkic and Tungusic, see Shimunek 2017), historical comparative approaches of textile vocabulary across the Transeurasian languages are virtually non- 
existent. Archaeological studies on textile production in the Neolithic and Bronze Age in the Transeurasian-speaking region are somewhat more numerous and focus on specific regions such the Russian Far East (Hyland et al. 2002; Furusawa 2007; Kuzmin et al. 2012), Korea (Choi H 1985; Choi D-J 2011) and Japan (Fujimura 1985; Nunome 1985, 1995; Takeuchi 1985; Cort 1989; Ozeki 2018; Noshiro and Sasaki 2014). However, none of these studies provides a cross-regional comparison of textile technology.

Here we intend to fill a gap in the current literature, not only by comparing words and tools for textile production across North and East Asia, but also by integrating the linguistic and archaeological evidence in a single approach, for which we use the term 'archaeolinguistics'. Other studies that have examined the connections between textile traditions, linguistic phylogenies and population histories in Eurasia include Buckley's (2012) research of the spread of Southeast Asian Neolithic weaving technologies in association with the expansion of the Austronesian languages and Tehrani et al.'s (2010) cultural evolutionary studies of Iranian tribal carpets. However, an integrative study examining parallels between early dispersal patterns of textile technology, farming, language and people has not yet been undertaken for North and East Asia. Through our holistic approach, we hope to remedy this situation and contribute to the current understanding of ancient population movements in North and East Asia.

\section{Methods}

\section{Linguistic paleontology}

First, it is necessary to look in somewhat more detail at the linguistic methods to be used in addressing the problem. We are dealing with the ancestral language of the Transeurasian languages, conventionally called 'proto-Transeurasian'. This language is not attested in written records and is separated by several millennia from the earliest attested written sources of Old Turkic, Middle Mongolian, Jurchen, Middle Korean and Old Japanese. Nevertheless, it is possible to reconstruct this language by 'unwinding' regular and systematic similarities among the attested Transeurasian languages. In particular, we are concerned with the vocabulary of proto-Transeurasian as a way of determining the material culture of the speakers of that language, especially the ways in which it reflects the degree of familiarity with textile production. How can we tell what the vocabulary of proto-Transeurasian was like in this domain? Linguistic paleontology is a subfield of comparative historical linguistics that enables us to study human prehistory by correlating our linguistic reconstructions with information from archaeology about the possible cultural and natural environment of the speakers of the proto-language. The method was first introduced under this label by Adolphe Pictet (1859), but it is also known as 'cultural reconstruction' (Epps 2015) or 'Wörter und Sachen technique' (Campbell 2004 [1998], pp. 367-368). It relies on two assumptions, specifically, first, that words and their meanings can be confidentially reconstructed to the proto-language, and second, that reconstructed words allow us to make direct inferences about the culture of the ancient speech communities that used these words. However, the method is by no means foolproof. First, semantic reconstruction is generally less precise than phonological reconstruction. Second, the repurposing of words with a non-cultural meaning as words with a cultural meaning after the importation of a specific technology might erroneously lead us to attribute this word to the proto-language. For instance, an unattentive linguist might erroneously attribute the word 'mouse' in the meaning of 'computer device' to the proto-Germanic language because this meaning is disseminated across most of the contemporary Germanic languages. Third, if we can only reconstruct a single cultural item, say one word for 'weaving' that is not backed up by other members of its semantic domain, in casu textile production, there is reason for suspicion. Finally, as the traditional aphorism goes, 'absence of evidence is not evidence of absence'. The observation that there is no proto-Transeurasian reconstruction for 'hand', for instance, would hardly lead to the conclusion that the ancestral speakers of Transeurasian lacked hands. In the same way, the lack of a reconstruction for 'spindle whorl' may be explained by the fact that the ancestral speakers were not familiar with spindle whorls, but it could also be due to the innovation and replacement of the common word for 'spindle whorl' over time. Nevertheless, when combined with the stringent 


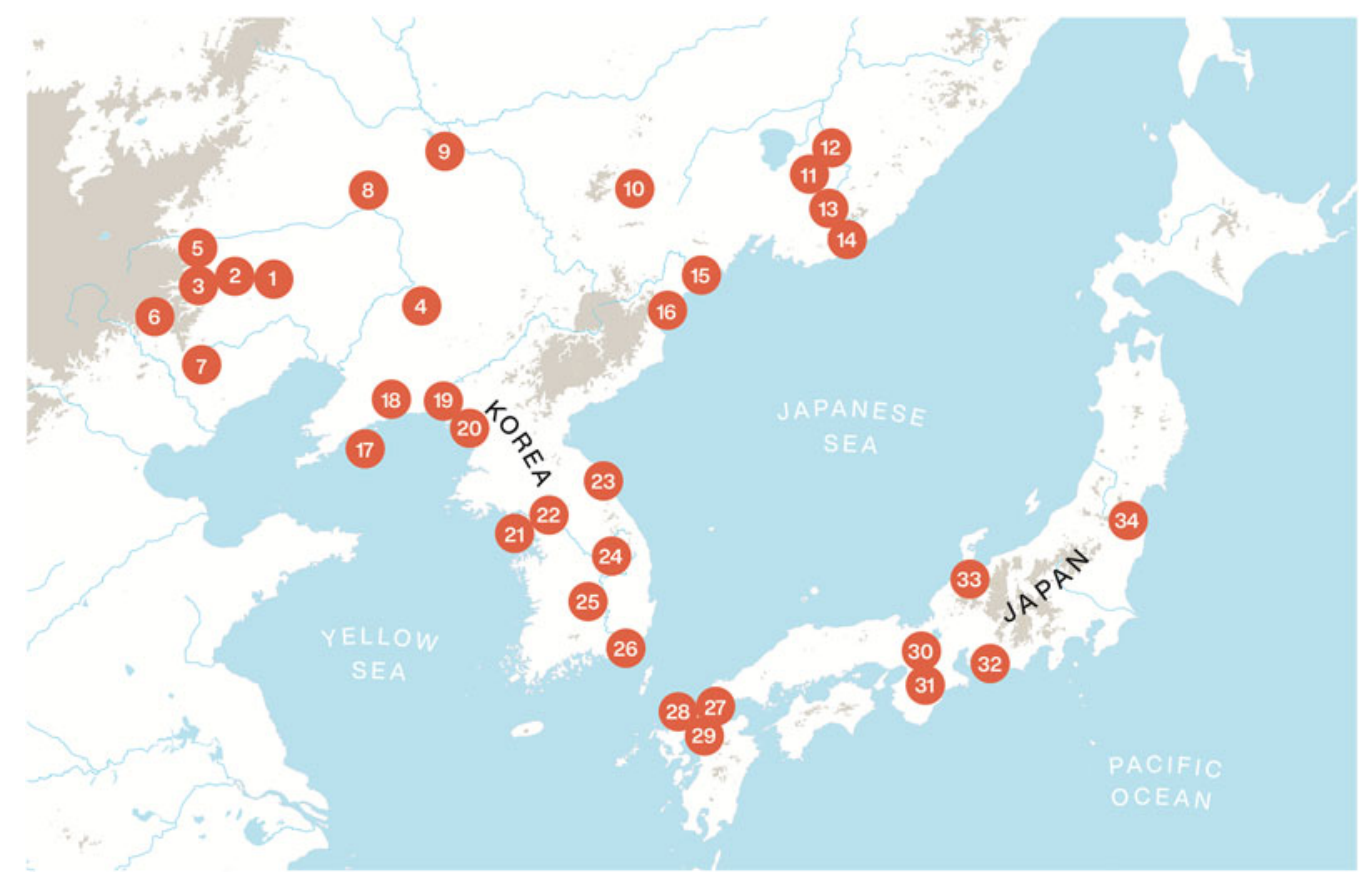

Figure 2. Location of the archaeological sites reviewed in this study: 1 , Xinglongwa (6400-5200 BCE); 2, Zhaobaogou (5400-4500 BCE); 3, Baiyinchanghan II (5400-4500 BCE); 4, Xinle (5500-4800 BCE); 5, Jiefangyingzi (4500-3000 BCE); 6, Weijiawopu (4500-4000 BCE); 7, Niuheliang (4500-3000 BCE); 8, Haminmangha (4000-3000 BCE); 9, Zuojiashan (3000-2600 BCE); 10, Lower Yinggeling (2000 BCE); 11, Siny Gai A lower layer (ca. 2000-1300 BCE); 12, Bogolyubovka-1 (ca. 1900 BCE); 13, Sheklyaevo 7 Upper Zaisanovka horizon (ca. 2000-1300 BCE); 14, Valentin Peresheek (2600-1900 BCE); 15, Sŏp'ohang (ca. 3000 BCE); 16, Nongpodong (ca. 3000 BCE); 17, Xiaozhushan III (4500-3300 BCE); 18, Lower Houwa (4350-3000 BCE); 19, Sinam-li (ca. 3000 BCE); 20, Upper Kungsan-li (3100 BCE); 21, Jungsandong (2250-2140 BCE); 22, Amsadong (4230-1430 BCE); 23, Osan-li (5050-2230 BCE); 24, Pangokdong (23001500 BCE); 25, Pibong-li (5010-3050 BCE); 26, Tongsamdong (4740-1800 BCE); 27, Sasai (ca. 800 BCE); 28, Nabatake (ca. $900-$ 400 BC); 29, Yoshinogari (ca. 500 BC-AD 300); 30, Karako-Kagi (ca. 500 BC-AD 300); 31, Shimonagata B (300BCE-300AD); 32, Ikegami (ca. 400 BC-AD100); 33, Shiraiwa (ca. 300 BCE); 34, Youkaijichikata (ca. 300 BCE).

checks and balances of the historical comparative method, linguistic paleontology is reasonably robust as a way of determining proto-culture through proto-language. Therefore, we will apply this method in order to make predictions about the familiarity with textile production of the ancestral Transeurasian speakers.

\section{Archaeolinguistic mapping}

Next, we will test these predictions through a comparative survey of textile technology in Northeast Asia in the Neolithic and Bronze Age. For this purpose, we will examine 34 archaeological sites that have evidence for spindle whorls covering the West Liao River area in Northeast China, the Russian Far East, the Korean Peninsula and the Japanese Islands from the Neolithic to the Bronze Age. The location and dating of these sites are presented in Figure 2.

Our aim is to examine whether the agricultural societies in this region had access to the textile technologies appearing in our linguistic reconstructions. We will therefore rely on a comparative analysis of existing data with regard to the presence of millet and hemp cultivation and the use of needles, awls, spindle whorls and loom weights. Our comparison of different sites at different time depths will lead to inferences about the route of dispersal of textile technology and to determining correlations and discrepancies with the dispersal route of agriculture. Mapping cultural dispersal on linguistic phylogeny, we will correlate these expansive processes inferable from the archaeological record with the linguistic spreads visible in Transeurasian language classification. In this way, archaeolinguistic 
mapping will serve to visualize to what extent the ancient dispersal routes of textile and agriculture overlap and mirror the spreads of the Transeurasian ancestral languages.

\section{Analysis}

\section{Linguistic reconstructions}

We may now turn to the evidence for the reconstruction of textile vocabulary to proto-Transeurasian. An overview of the linguistic cognates as well as a detailed dataset underlying our analysis can be found in Supplementary Table S1. Based on our dataset, we can reconstruct a verb for making rope, pTEA *nap- 'to make rope' and two verbs for sewing, pTEA *nup- 'to sew' and pTEA *sili- 'to sew', but these may refer to activities connected to the production of textiles found at pre-agricultural sites and do not necessarily associate the speakers of proto-Transeurasian with a Neolithic society. Indeed, sewing and the manufacture of cordage do not need to imply weaving. The earliest actual textiles found preserved in East Asia so far are dated to the Early Neolithic Rudninskaya archaeological culture, $9400-8400 \mathrm{cal}$ BP by AMS dating. Parts of ropes, nets and mats, produced without spindlewhorl technology, were found in the Chertovy Vorota Cave in the Primorye Province of the Russian Far East (Kuzmin et al. 2012). Impressions of cord and cloth were found in the earliest known pottery in the Russian Far East, for example at the Gromatukha site in the Middle Amur basin dated to around 12500 BCE in the early Holocene (Hyland et al. 2002). Actual fragments of rope and string along with willow basketwork have been found at Angangxi, now a desert site in western Manchuria, ca. 60007000 BCE (Chang 1986, p. 64). Jomon pottery, some of the earliest pottery found in East Asia beginning around 14,500 BCE, is named for its cord-marked impressions (Kaner 2009; Matsuura 2017), although there is no evidence of any kind of plant cultivation at that time. In Japan, baskets are known from as early as 5760-5980 cal BCE at the Higashimyō site (Saga) (Kuzmin et al. 2012).

More strikingly, we can attribute verbs for weaving and spinning to proto-Transeurasian such as pTEA ${ }^{\star}$ pors- 'to weave (cloth)' and pTEA *toms- 'to spin', which seem to be related to more sophisticated processes of textile production in the Neolithic. Firm archaeological evidence of woven cloth and production tools for weaving and spinning begins later than that for rope and twine. Conical spindle whorls, ceramic disks described as spindle whorls and 'net' weights that in reality may be loom weights are often listed in site reports in Neolithic East Asia. Rope belts on otherwise nude figures and costumes depicted on figurines in the Hongshan period (4500-2900 BCE) provide another insight into Late Neolithic textile use (Childs-Johnson 2001, pp. 19-20).

The device associated with early textile production in Northeast Asia is the loom, either a horizontal back strap loom or a vertical warp weighted loom (Omura and Kizawa 2017; Kuzmin et al. 2012). The latter device, a wooden frame consisting of two vertical posts with a horizontal beam between them, required the attachment of net weights to the lower ends of plant fibers to stretch them out (Kent and Nelson 1976). The backstrap loom, which did not require weights, was more widespread in the Yellow River region and to the south of it.

We can further reconstruct a verb * giri- 'to cut' to proto-Transeurasian that seems to have been especially applied in the domain of textile production because the instrumental nouns derived from the relevant verbs in Old Japanese and Manchu both refer to an instrument restricted to cutting cloth and the corresponding Turkic verbs are specialized for the cutting of strips of pelt or cloth. In absence of scissors, stone knives were used to cut hemp and other products during the Neolithic in Northeast Asia (An 1955).

While the proto-Transeurasian textile vocabulary often gets lost in Turkic and Mongolic languages, it is well preserved in Japonic and Koreanic languages. In addition, there are three instances of common textile vocabulary restricted to proto-Japano-Koreanic, i.e. $\mathrm{pJK}{ }^{\star}$ parı- 'to sew', $\mathrm{pJK}{ }^{\star} p u$ - 'to spin, twist (thread)', pJK * pata- 'to weave (cloth) with a loom' and pJK *asa 'hemp'. This seems to indicate that Transeurasian-speaking populations moving eastwards with agriculture retained more 'traditional' technologies such as textile production whereas those moving westwards were more exposed to west 
Eurasian technologies and replaced their vocabulary accordingly. Although archaeologists rarely find any differentiation between sites with agriculture and sites specializing in herding in terms of the appearance of spindle whorls, the site of Maoqinggou (740-345 BCE), just outside the Yan Wall in Manchuria, is an exception in that it shows significant differences in burials between agricultural and pastoral people. The tombs that exclusively contain spindle whorls are oriented north-south and imply an agricultural economy, while east-west-oriented graves lack spindle whorls and imply a pastoralist economy (Wu 2007). This may suggest that the herders were supplied with cloth by the agricultural weavers, while they may have been supplying wool to the weavers (Wu 2004, p. 229). Therefore, weaving seems to be associated more closely with agricultural people than with pastoral people living at the same time in the same region.

Genes are always inherited by offspring from their parents, and so are languages and material culture in many cases, but not always because social phenomena may disrupt the horizontal transmission. Tools for textile production are expected to become vertically transmitted from parents to their offspring along with the words referring to them. However, sometimes these traditions may be acquired from sources other than the immediate ancestors by way of horizontal transmission, for instance, through cultural influence from neighboring populations. Linguistically, we can exclude borrowing with a high degree of probability for the etymologies above. Owing to a number of linguistic indications such as the regularity of sound correspondence, the lack of morphological segmentability of the involved comparanda, the multiple rather than binary comparative setting including up to five daughter branches and the solid distribution of cognates in individual daughter branches, these etymologies are considered to be relatively borrowing-proof. However, a few comparative sets relating to textile technology are indicative of borrowing rather than inheritance because they display problematic sound correspondences, are morphologically segmentable, have a limited distribution in some daughter branches or match a probable donor word outside the family. This may be the case for both cognate sets for 'hemp' included in Supplementary Table S1.

The high tone of MK sam 'hemp' indicates the loss of an initial vowel and justifies the reconstruction of *asam 'hemp (Cannabis sativa)' to proto-Japano-Koreanic. However, the attestation of an Old Indo-Aryan śan 'hemp' in the ancient religious hymns of the Rigveda from the second millennium BCE, which goes back to an even older Scythian form *sana 'hemp' (Mayrhofer 1992-2001, p. 605; Gamkrelidze and Ivanov 1995, p. 570) may indicate that this common form is ultimately borrowed from the west. Contact may also explain the correlations yielding the reconstruction of proto-Altaic *olo 'hemp' because the form has a limited distribution in Tungusic: it is restricted to Manchu only and may be borrowed from Mongolic. As Manchu does not reflect the Mongolic collective suffix ${ }^{*}$-sun the borrowing should precede proto-Mongolic and have taken place not later than the first millennium AD. There are different hypotheses on the origin of hemp domestication, of which the two most frequently cited refer either to China (Crawford 2006) or Central Asia (Russo 2007) as the domestication center. From the third millennium onwards, there is an increase in evidence of cannabis remains from East Asia, which may be associated with an exchange network through the Eurasian steppe zone (Long et al. 2017). The borrowing of the words for hemp may be seen in this context. The current evidence suggests that the use of fibers from wild plants preceded the cultivation of plants such as hemp for this purpose. Sarah Nelson (2017) infers that at the Amsadong site in the Early Korean Neolithic wild plants were used for weaving and medicine as well as unspecified cultivated plants. Lee Gyoung-Ah (pc 01.09.2019) reidentified hemp discovered earlier at the Neolithic Taych'on-li site in Ch'ungch'ŏng province as a soil clump. The current stage of research is such that there are no hemp remains prior to the Early Iron Age in Korea. In Japan, however, small-scale cultivation of hemp probably dates back to the Early Jomon period (Kudo and Hitoki 2014; Noshiro and Sasaki 2014).

Ramie, a plant that is native to Northeast Asia was a widespread fiber in Neolithic and Bronze Age that was used for textile production and subject to intentional soaking. However, we do not find comparative sets that are indicative of a common ancestral word for this plant. 
Surprisingly, at least three different verbs for 'soaking' can be reconstructed for Transeurasian, pTEA * simi- 'to soak', pTEA *ulu- 'to soak, wet' and pTEA * nor- 'to soak' in addition to *deb- 'to soak' in proto-Altaic and ${ }^{\star} k a m$ - 'to wash, soak' in proto-Japano-Koreanic. Why did the ancestral speakers of Transeurasian need so many different verbs for soaking? One explanation could be connected to food production, for instance, in the Neolithic, nuts were soaked to remove the tannic acid (Kawashima 2016). However, as a number of soaking verbs developed secondary meanings such as 'to stain', 'to paint' and 'to bleach' or derived nouns meaning 'clothes', some may be connected to textile production. As evident from the present-day commercial production process in Northeast Asia, tree bark, ramie and hemp need to be soaked before they can be turned into thread, and hemp strips and thread are repetitively soaked and heated in the process of weaving (Clarke 2006).

\section{From linguistic inferences to archaeological predictions}

In addition to the availability of agricultural vocabulary, Robbeets $(2017,2020 \mathrm{a})$ used the linguistic dating and the location of the ancestral nodes in the Transeurasian family to associate ancestral languages with archaeological cultures. Bayesian phylogenetic analysis infers the time depths of separation at $4700 \mathrm{BCE}$ for proto-Transeurasian, $3293 \mathrm{BCE}$ for proto-Altaic, $1552 \mathrm{BCE}$ for proto-Turko-Mongolic and $1850 \mathrm{BCE}$ for proto-Japano-Koreanic (Robbeets and Bouckaert 2018). Different methods for the determination of linguistic homelands converge on situating proto-Transeurasian, proto-Altaic and proto-Turko-Mongolic in the West Liao River region, proto-Tungusic in the southern part of the Primorye region of the Russian Far East and proto-Japano-Koreanic on the Liaodong Peninsula before the individual Transeurasian languages reached their present-day locations. The connections in space, time and subsistence mode suggest an association between language families and archaeological cultures, as presented in Supplementary Table S2.

This association between ancestral languages and archaeological cultures leads to at least three predictions. First, since the speakers of proto-Transeurasian used vocabulary for weaving and spinning, we infer that they were familiar with these techniques. This gives rise to the expectation to find evidence for weaving and spinning in the Xinglongwa (6200-5400 BC) and Zhaobaogou (5400-4500 BC) cultures in the West Liao River region, such as loom weights and spindle whorls.

Second, since Transeurasian textile vocabulary solidly survived in the Japano-Koreanic and Tungusic subgroups, we infer that the speakers of Transeurasian took their knowledge of spinning and weaving with them on their journey to the southern part of the Primorye and the Liaodong Peninsula and from there over the Korean Peninsula to Japan. We therefore predict a connection between Neolithic spindle whorls in the Liao River Basin and those of the Neolithic on the Liaodong Peninsula, the southern part of the Primorye region and the Korean Peninsula as well as Bronze Age Japan.

Third, since the ancestral Transeurasian proto-languages display cognate textile vocabulary in addition to agricultural vocabulary, we infer that words for textile and agriculture were spread simultaneously by the early speakers. We predict that Neolithic and Bronze Age cultures with evidence for spindle whorls will tend to preserve evidence for agriculture and that we cannot find spindle whorls preceding agriculture in North and East Asia.

\section{Results}

Prediction 1: Earliest evidence for spindle whorls in the Transeurasian linguistic region goes back to the Xinglongwa and Zhaobaogou cultures

In order to test these predictions, we examined the Neolithic and Bronze Age archaeological sites in Northeast Asia with evidence for textile technology presented in Figure 2. Table 1 gives an overview of these sites and specifies whether there is evidence for millet cultivation, agricultural tools, hemp 


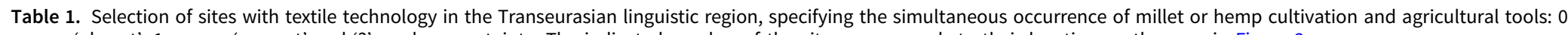
means 'absent', 1 means 'present' and '?' marks uncertainty. The indicated number of the sites corresponds to their location on the map in Figure 2

\begin{tabular}{|c|c|c|c|c|c|c|c|c|c|}
\hline Region & Culture & $\begin{array}{l}\text { Site no.; } \\
\text { Figure } 2\end{array}$ & Site name/date & $\begin{array}{c}\text { Millet } \\
\text { cultivation }\end{array}$ & $\begin{array}{l}\text { Agricultural } \\
\text { tools }\end{array}$ & $\begin{array}{l}\text { Hemp } \\
\text { cultivation }\end{array}$ & $\begin{array}{l}\text { (Bi)conical } \\
\text { spindle } \\
\text { whorl }\end{array}$ & $\begin{array}{c}\text { Flat } \\
\text { spindle } \\
\text { whorl }\end{array}$ & $\begin{array}{c}\text { Bone } \\
\text { needle/ } \\
\text { awl }\end{array}$ \\
\hline & Northeast China & & & & & & & & \\
\hline Liao River & $\begin{array}{l}\text { Xinglongwa } \\
\quad 6400-5200 \text { BCE }\end{array}$ & 1 & $\begin{array}{l}\text { Xinglongwa } \\
\quad 6400-5200 \text { BCE }\end{array}$ & 1 & 1 & 0 & 0 & 1 & 1 \\
\hline Liao River & $\begin{array}{l}\text { Xinglongwa } \\
5400-4500 \text { BCE }\end{array}$ & 3 & $\begin{array}{l}\text { Baiyinchanghan II } \\
6400-5400 \text { BCE }\end{array}$ & $1 ?$ & 1 & 0 & 1 & 1 & 1 \\
\hline Liao River & $\begin{array}{l}\text { Zhaobaogou } \\
\quad 5400-4500 \text { BCE }\end{array}$ & 2 & $\begin{array}{l}\text { Zhaobaogou } \\
5400-4500 \text { BCE }\end{array}$ & 0 & 1 & 0 & 0 & 1 & 1 \\
\hline $\begin{array}{l}\text { Lower Liao River } \\
\text { (Shenyang) }\end{array}$ & $\begin{array}{l}\text { Xinle } \\
\qquad 5200-4000 \text { BCE }\end{array}$ & 4 & $\begin{array}{l}\text { Upper Xinle } \\
\quad 4800-4000 \text { BCE }\end{array}$ & $1 ?$ & 1 & 0 & 1 & 1 & 1 \\
\hline Liao River & $\begin{array}{l}\text { Hongshan } \\
\quad 4500-3000 \text { BCE }\end{array}$ & 5 & $\begin{array}{l}\text { Jiefangyingzi } \\
\quad 4500-3000 \text { BCE }\end{array}$ & No data & No data & No data & 1 & 1 & No data \\
\hline Liao River & $\begin{array}{l}\text { Hongshan } \\
\qquad 4500-3000 \text { BCE }\end{array}$ & 6 & $\begin{array}{l}\text { Weijiawopu } \\
\quad 4500-4000 \text { BCE }\end{array}$ & 1 & 1 & 0 & 0 & $1 ?$ & 0 \\
\hline Liao River & $\begin{array}{l}\text { Hongshan } \\
\qquad 4500-3000 \text { BCE }\end{array}$ & 7 & $\begin{array}{l}\text { Niuheliang } \\
\qquad 4500-3000 \text { BCE }\end{array}$ & 0 & 1 & 0 & 0 & $1 ?$ & 1 \\
\hline Liao River & $\begin{array}{l}\text { Haminmangha } \\
\text { 3500-3000 BCE }\end{array}$ & 8 & $\begin{array}{l}\text { Haminmangha } \\
\text { 4000-3000 BCE }\end{array}$ & 1 & 1 & 1 & 0 & 1 & 1 \\
\hline Amur River & $\begin{array}{l}\text { Zuojiashan } \\
\quad 4000-600 \text { BCE }\end{array}$ & 9 & $\begin{array}{l}\text { Zuojiashan } \\
\text { 2600-3000 BCE }\end{array}$ & 1 & 1 & 0 & 0 & 1 & 1 \\
\hline Amur River & $\begin{array}{l}\text { Yinggeling } \\
\quad 4000-1000 \text { BCE }\end{array}$ & 10 & $\begin{array}{l}\text { Lower Yinggeling } \\
2000 \text { BCE }\end{array}$ & 0 & 1 & 0 & 1 & 1 & 1 \\
\hline Yalu River & $\begin{array}{r}\text { Xiaozhushan (I-V) } \\
4700-2100 \text { BCE }\end{array}$ & 17 & $\begin{array}{l}\text { Xiaozhushan III 4500- } \\
3300 \text { BCE }\end{array}$ & 1 & 1 & 0 & 0 & $1 ?$ & 1 \\
\hline Yalu River & $\begin{array}{l}\text { Houwa } \\
\quad 4500-3000 \text { BCE }\end{array}$ & 18 & $\begin{array}{l}\text { Lower Houwa } \\
\quad 4350-3000 \text { BCE }\end{array}$ & 0 & 1 & 0 & 0 & 1 & 1 \\
\hline
\end{tabular}


Southern part of Primorye Province of Russian Far East

\begin{tabular}{|c|c|c|c|c|c|c|c|c|c|}
\hline $\begin{array}{l}\text { Khanka-Ussuri } \\
\text { Plain, east of } \\
\text { Lake Khanka }\end{array}$ & $\begin{array}{l}\text { Zaisanovka } \\
\quad 3200-1500 \text { BCE }\end{array}$ & 11 & $\begin{array}{l}\text { Siny Gai A- } \\
\text { lower layer } \\
\text { ca. 2000-1300 BCE }\end{array}$ & No data & 1 & No data & 1 & 1 & 1 \\
\hline Eastern seacoast & $\begin{array}{l}\text { Zaisanovka } \\
\quad 3200-1500 \text { BCE }\end{array}$ & 14 & $\begin{array}{l}\text { Valentin-Peresheek } \\
2900-2300 \text { BCE }\end{array}$ & No data & 1 & No data & 1 & 1 & 0 \\
\hline $\begin{array}{c}\text { East of Khanka- } \\
\text { Ussuri Plain }\end{array}$ & $\begin{array}{l}\text { Zaisanovka } \\
\quad 3200-1500 \text { BCE }\end{array}$ & 13 & $\begin{array}{l}\text { Sheklyaevo } 7 \\
\text { Upper Zaisanovka } \\
\text { horizon } \\
\text { ca. } 2000-1300 \text { BCE }\end{array}$ & 1 & No data & 0 & 0 & 1 & No data \\
\hline \multirow{2}{*}{$\begin{array}{l}\text { Khanka-Ussuri } \\
\text { Plain, south of } \\
\text { Lake Khanka }\end{array}$} & $\begin{array}{l}\text { Zaisanovka } \\
\quad 3200-1500 \text { BCE }\end{array}$ & 12 & $\begin{array}{c}\text { Bogolyubovka-1 } \\
\text { Ca. } 1900 \text { BCE }\end{array}$ & 1 & 1 & 0 & 0 & 1 & No data \\
\hline & Korean Peninsula & & & & & & & & \\
\hline $\begin{array}{l}\text { Yangyang, } \\
\text { Kangwŏndo }\end{array}$ & $\begin{array}{l}\text { Early Chulmun } \\
\quad 6000-3500 \text { BCE }\end{array}$ & 23 & $\begin{array}{l}\text { Osan-li } \\
\quad 5050-2230 \text { BCE }\end{array}$ & 0 & 1 & 0 & 1 & 0 & No data \\
\hline $\begin{array}{l}\text { Changnyŏng, South } \\
\text { Kyŏngsang }\end{array}$ & $\begin{array}{l}\text { Early Chulmun } \\
\quad 6000-3500 \text { BCE }\end{array}$ & 25 & $\begin{array}{l}\text { Pibong-li } \\
\text { 5010-3050 BCE }\end{array}$ & 1 & 1 & 0 & 1 & 1 & No data \\
\hline Seoul & $\begin{array}{l}\text { Early-Middle } \\
\text { Chulmun } \\
6000-2000 \text { BCE }\end{array}$ & 22 & $\begin{array}{l}\text { Amsadong } \\
\quad 4230-1430 \text { BCE }\end{array}$ & 1 & 1 & 0 & 1 & 1 & No data \\
\hline Tumen River & $\begin{array}{l}\text { Middle-Late Chulmun } \\
\quad 3500-1500 \text { BCE }\end{array}$ & 15 & Sŏp'ohang & 0 & 1 & 0 & 1 & 0 & 0 \\
\hline Tumen River & $\begin{array}{l}\text { Middle-Late Chulmun } \\
\quad 3500-1500 \text { BCE }\end{array}$ & 16 & Nongpodong & 0 & 1 & 0 & 1 & 0 & No data \\
\hline Yalu River & $\begin{array}{l}\text { Middle-Late Chulmun } \\
\text { 3500-1500 BCE }\end{array}$ & 19 & $\begin{array}{l}\text { Sinam-li } \\
\quad 3000 \text { BCE }\end{array}$ & 0 & 1 & 0 & 1 & 1 & 0 \\
\hline Taedong River & $\begin{array}{l}\text { Middle-Late Chulmun } \\
\quad 3500-1500 \text { BCE }\end{array}$ & 20 & $\begin{array}{l}\text { Upper Kungsan-li } \\
3100 \text { BCE }\end{array}$ & $1 ?$ & 1 & 0 & 1 & 1 & 1 \\
\hline $\begin{array}{l}\text { Nakdong River, } \\
\text { Pusan }\end{array}$ & $\begin{array}{l}\text { Middle-Late Chulmun } \\
\quad 3500-1500 \text { BCE }\end{array}$ & 26 & $\begin{array}{l}\text { Tongsamdong } \\
4740-1800 \mathrm{BCE}\end{array}$ & 1 & 1 & 0 & 1 & 1 & 1 \\
\hline Incheon & $\begin{array}{l}\text { Late Chulmun } \\
2000-1500 \text { BCE }\end{array}$ & 21 & $\begin{array}{l}\text { Jungsandong } \\
2250-2140 \text { BCE }\end{array}$ & 1 & 1 & 0 & 1 & 1 & No data \\
\hline
\end{tabular}


Table 1. (Continued.)

\begin{tabular}{|c|c|c|c|c|c|c|c|c|c|}
\hline Region & Culture & $\begin{array}{l}\text { Site no.; } \\
\text { Figure } 2\end{array}$ & Site name/date & $\begin{array}{c}\text { Millet } \\
\text { cultivation }\end{array}$ & $\begin{array}{l}\text { Agricultural } \\
\text { tools }\end{array}$ & $\begin{array}{l}\text { Hemp } \\
\text { cultivation }\end{array}$ & $\begin{array}{l}\text { (Bi)conical } \\
\text { spindle } \\
\text { whorl }\end{array}$ & $\begin{array}{c}\text { Flat } \\
\text { spindle } \\
\text { whorl }\end{array}$ & $\begin{array}{c}\text { Bone } \\
\text { needle/ } \\
\text { awl }\end{array}$ \\
\hline \multirow[t]{2}{*}{ Wonju, Kangwŏndo } & $\begin{array}{l}\text { Late Chulmun } \\
2000-1500 \text { BCE }\end{array}$ & 24 & $\begin{array}{l}\text { Pangokdong } \\
2300-1500 \text { BCE }\end{array}$ & 1 & 1 & 0 & 1 & 0 & No data \\
\hline & Japanese Islands & & & & & & & & \\
\hline Fukuoka & $\begin{array}{l}\text { Yayoi } \\
\quad 900 \mathrm{BCE}-300 \mathrm{AD}\end{array}$ & 27 & $\begin{array}{l}\text { Sasai } \\
\quad \text { ca. } 900 \text { BC-600BCE }\end{array}$ & 0 & 1 & 0 & 0 & 1 & 1 \\
\hline Saga & $\begin{array}{l}\text { Yayoi } \\
\text { 900BCE-300AD }\end{array}$ & 28 & $\begin{array}{l}\text { Nabatake } \\
\text { ca. } 900-400 \text { BCE }\end{array}$ & 1 & 1 & 0 & 0 & 1 & 1 \\
\hline Saga & $\begin{array}{l}\text { Yayoi } \\
\text { 900BCE-300AD }\end{array}$ & 29 & $\begin{array}{l}\text { Yoshinogari } \\
\text { ca. } 500 \text { BCE-AD } 300\end{array}$ & 0 & 1 & 1 & 0 & 1 & 0 \\
\hline Nara & $\begin{array}{l}\text { Yayoi } \\
\text { 900BCE-300AD }\end{array}$ & 30 & $\begin{array}{l}\text { Karako-Kagi } \\
\text { ca. } 500 \text { BCE-AD } 300\end{array}$ & 0 & 1 & 0 & 0 & 1 & 0 \\
\hline Osaka & $\begin{array}{l}\text { Yayoi } \\
\text { 900BCE-300AD }\end{array}$ & 31 & $\begin{array}{l}\text { Ikegami } \\
\text { ca. } 400 \text { BCE-AD100 }\end{array}$ & 0 & 1 & 0 & 0 & 1 & 0 \\
\hline Shizuoka & $\begin{array}{l}\text { Yayoi } \\
\text { 900BCE-300AD }\end{array}$ & 32 & $\begin{array}{l}\text { Shiraiwa } \\
\text { ca. } 200 \text { BCE-AD } 200\end{array}$ & 0 & 1 & 0 & 0 & 1 & 0 \\
\hline Ishikawa & $\begin{array}{l}\text { Yayoi } \\
\text { 900BCE-300AD }\end{array}$ & 33 & $\begin{array}{l}\text { Yōkaichijikata } \\
\text { ca. } 300 \text { BCE-AD } 200\end{array}$ & 0 & 1 & 0 & 0 & 1 & 1 \\
\hline Fukushima & $\begin{array}{l}\text { Yayoi } \\
\text { 900BCE-300AD }\end{array}$ & 34 & $\begin{array}{l}\text { Shimonagata B } \\
\text { ca. } 300 \text { BCE-AD } 300\end{array}$ & 0 & 0 & 0 & 0 & 1 & 0 \\
\hline
\end{tabular}


cultivation, spindle whorls and bone needles or awls. The feature 'agricultural tools' refers to the discovery of stone, clay or wooden artifacts that are assumed to have been used in agricultural activities, such as plowing and harvesting.

Spindle whorls indeed appear as early as the Xinglongwa culture, the first farming culture in Northeast China. They continue through the Zhaobaogou culture into the Hongshan culture, also covering outlying Neolithic cultures such as Haminmangha on the eastern plains of the West Liao River, Xinle in the Lower Liao River basin and Houwa and Xiaozhushan on the Liaodong Pensinula. Sites in Jilin dating to the third millennium BCE also display spindle whorls.

The evidence for spindle whorls continues into the Russian Far East in the third and second millennia BC, where they appear at the Neolithic sites of Valentin-Peresheek (Andreeva, 1987; Zhushchikhovskaya, 2006), Siny Gai A lower layer (Zhushchikhovskaya, 2006; Brodyansky, 2013), Sheklyaevo-7 Upper Zaisanovka horizon (Klyev et al. 2003) and Bogolyubovka-1 (Sergusheva, 2013; Garkovik and Sergusheva, 2014). These sites represent different local variants of the Zaisanovka cultural tradition. Most datings are marked as 'ca.', indicating that there is no carbon dating available for the sites. The Valentin-Peresheek and Siny Gai A preserve evidence for conical, biconical and flat disklike spindle whorls. The Bogolyubovka-1 site, which is located not far from Siny Gai, produced a series of earthenware flat disks similar to the Siny Gai A ones. Sheklyaevo-7, east from Siny Gai, is a smallsized settlement with complicated stratigraphy, but the flat disk-like whorls in the Upper Zaisanovka horizon are interpreted as late Neolithic, Zaisanovka culture. Although the Siny Gai and Valentin-Peresheek sites belong to different landscape-climatic zones, the temporal difference between them is insignificant. In general, the artifact assemblage from Siny Gai looks somewhat more developed than the one from Valentin-Peresheek.

For the Korean Neolithic, spindle whorls are reported in northern as well as southern sites. Most sites are dated to the Middle to Late Chulmun period but the water-logged site of Pibong-li in southeastern Korea (Kimhae National Museum 2018), the Amsadong site (Nelson 2017) and the Osan-li site are dated to the Early Chulmun period. Pibong-li adds details about early use of plants for textiles. Bags woven from grass were found near a piece of a wooden boat. The dates are $4670 \pm 60 \mathrm{BCE}$, making the site as old as Amsadong and showing that plant usage for weaving occurred even in the south of the Korean peninsula in the Early Neolithic. Further studies of seeds will expand our knowledge of cultivation at this important site, but in terms of textile production, many spindle whorls, needles and weights demonstrate a lively industry. This site, being close to Japan, may be a place from which textiles spread. Finds of weights and spindle whorls in Early (1300-800 BCE) and Middle Mumun (800$500 \mathrm{BCE}$ ) show that virtually every site contains spindle whorls as well as weights in Bronze Age Korea (Kim 1978; Lee 2019).

The first evidence of woven cloth in Japan is thought to have appeared in the early part of the Yayoi period (900 BC-AD 300) when spinning and weaving technologies were brought from Korea along with an agricultural package including rice and millets. Small-scale cultivation of hemp probably dates back to the Early Jomon period but ramie and silk are also known from Yayoi contexts. Nagasaki (1978) proposed that the perforated circular disks known from the Jomon period served as spindle whorls and this remains a possibility. Yayoi-period spindle whorls were made from clay, stone, wood or bone and antler, but those of clay or stone were the most common. Most Yayoi spindle whorls are flat and undecorated disks. However, a few incised decorations are known from Nabatake (Saga), Magarita (Fukuoka) and Shimonogata B (Fukushima). Conical spindle whorls were absent in the Yayoi but common in the Kofun period (AD 250-700). Wooden spindles are known from several Yayoi sites. At Kitoragawa (Osaka) a wooden spindle was found in association with a stone spindle whorl. Wooden parts of looms have been found at a number of Yayoi sites including Karako-Kagi and Toro (Takeuchi 1985). Needles from Yayoi contexts include one made from a sea urchin spine from Nabatake, and those made from bone from Asahi (Aichi), Ayaragi (Yamaguchi), and Kitoragawa.

In sum, although the attestation of spindle whorls in the southern part of the Korean Peninsula around $4600 \mathrm{BCE}$ is strikingly early, the earliest evidence for spinning technology in the 
Transeurasian-speaking region precedes this date by about a millennium and indeed comes from the Xinglongwa and Zhaobaogou cultures in the West Liao River basin.

\section{Prediction 2: Connection between Neolithic technology for spinning and weaving in the Liao River Basin and those in the southern part of the Primorye and on the Korean Peninsula as well as those in Bronze Age Japan}

Among the evidence for Neolithic and Bronze Age technology for spinning and weaving in Northeast Asia, we find conical or biconical spindle whorls, disk-like whorls and loom weights. A spindle whorl is a spherical tool that is fitted onto a spindle to increase and maintain the speed of the spin when twisting fibers and making threads. The spindle itself is a rounded, usually wooden, rod for twisting into thread the fibers pulled from the basic material. Suspended from the thread that is being spun, the spindle and whorl are controlled by the spinner. While there is no doubt that (bi)conical spindle whorls were used for spinning, the exact function of disk-like whorls, i.e. holed, flat disk-like objects, usually made from ceramic or stone, is not entirely clear. They may have been fitted individually onto the spindle as a whorl, but they may also have been used in conjunction, in hanging position as a system. Loom weights are ceramic or stone weights tied at the bottom of warp threads in a vertical loom to create an even tension and give greater control to the weaver.

Figure 3 compares the spinning and weaving technology from the Neolithic and Bronze Age in the West Liao River region, the southern part of the Primorye region, the Korean Peninsula and Japan. The spindle whorls in Figure 3a are similar in that they have a conical shape with a hole in the middle, are made from clay, are decorated with similar radiating or concentric patterns using pitting or incised line techniques and measure about $6 \mathrm{~cm}$ in diameter. Most examples in Figure 3a have a threedimensional conical shape, tapering smoothly from a flat circular base to a point, but biconical shapes, looking like two cones with their bases together, such as the Hongshan whorl in 2-3, are also found in the southern part of the Primorye and the Korean peninsula (Furusawa 2007, pp. 86-88). Whereas some spindle whorls, such as those in 1, 5 and 9, do not reflect any ornaments, others such as those in 3, 7 and 11 display a concentric, spiral-like design, while yet others, such as those in 4, 8, 10 and 12 form a pattern that radiates away from the center. The decorations in 6, 7, 10 and 11 are made by creating small holes, using a pitting technique, while those in 2, 3, 4, 8 and 12 display an incised line technique.

The whorls in Figure $3 \mathrm{~b}$ are similar in that they have a flat, disk-like shape with a hole in the middle, remain largely undecorated, are often but not always made from earthenware, come in sets of different sizes and are often reused from pottery fragments. Except for the Z-patterns on the whorls 1-3 from the Liao River Basin and the radiating incised lines on whorl 18 from Shimonagata B in Japan, most of the flat whorls remain undecorated. In addition to clay, they can also be made from stone or bone, such as the stone Hongshan whorls in 15 and some whorls belonging to the Zaisanovskaya culture (Furusawa 2007, p. 87). The whorls in 16-18 range between 2 and $6 \mathrm{~cm}$ in size and seem to form sets, which raises the possibility of them being used jointly in hanging position, perhaps as a kind of pulley system.

The ceramic weights in Figure $3 \mathrm{c}$ most probably are textile-producing equipment. From the Xinglongwa period (6200-5400 BC) onwards, stone weights are common in the Neolithic but usually these are reported without discussion as 'net sinkers or loom weights' (Wu and Liu 2003). However, these objects were arguably loom weights, as they have been more often found in houses rather than on shores where nets are kept, and they may be associated with spindle whorls. For example, small flat pebbles with notches in both ends have been found at Amsadong in Korea, where an argument could be made that that they are evidence of weaving rather than net-fishing, because the fish remains from that site are unimpressive (Nelson 1975; Kent and Nelson 1976). The loom weights can either have a hole in the middle, such as the weights in 21 and 23, or lack one, such as the weights in 20 and 22. They can be made from stone, such as the Xinglongwa weight in 20, but they are more generally made from earthenware, such as the weights in 21-23, because clay gives the weaver greater control over its shape, size and weight and is easier to pierce than rocks or pebbles. 


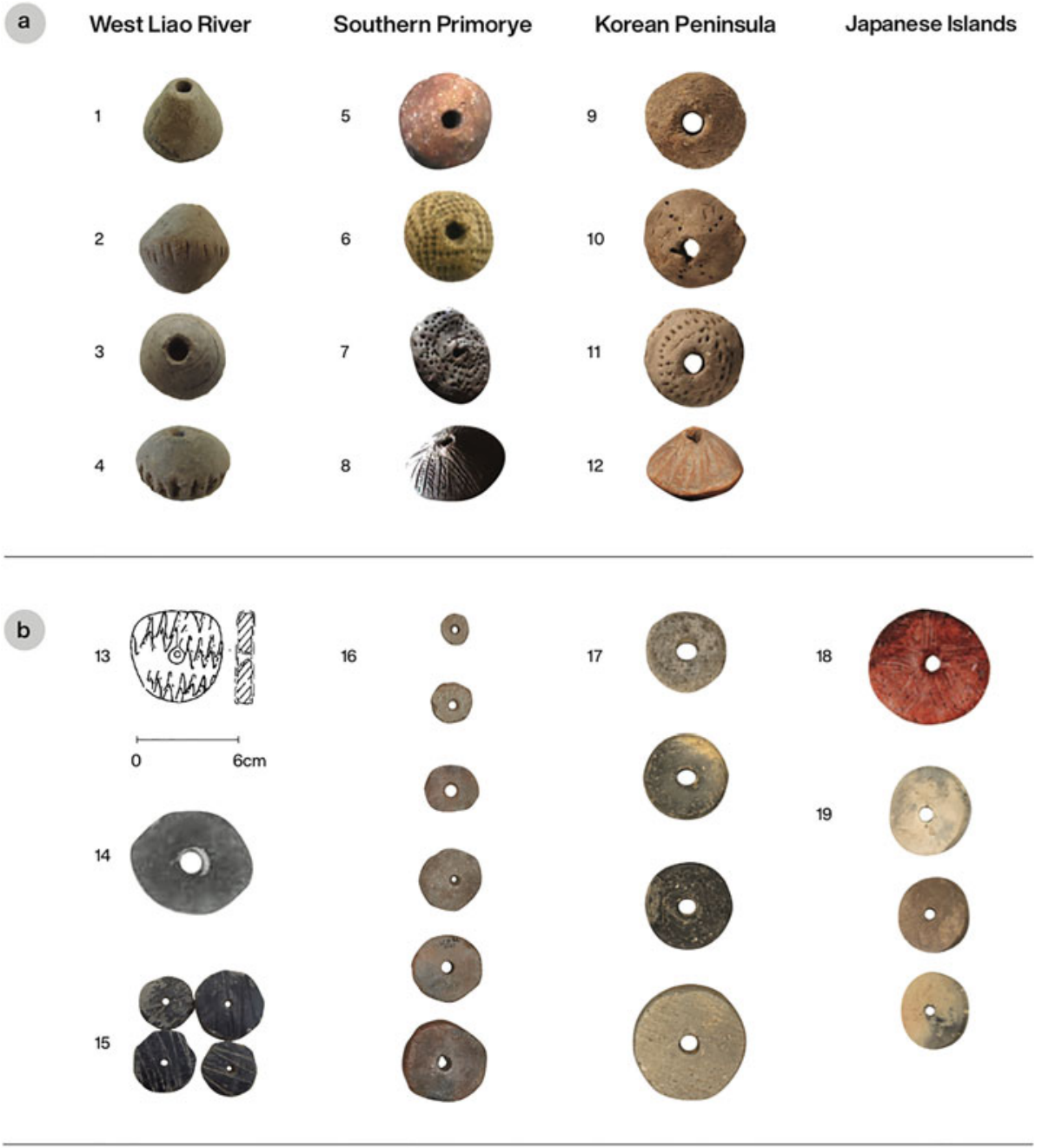

c

20

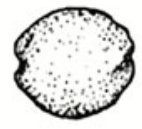

21

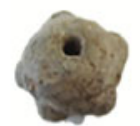

22

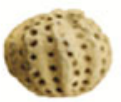

23

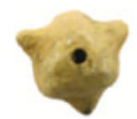

Figure 3. Comparison of spinning and weaving technology in Neolithic and Bronze Age Northeast Asia. (a) Conical ceramic spindle whorls: 1-4, Hongshan, Wengniute Banner, Inner Mongolia (http://blog.sina.cn); 5-6, Zaisanovskaya, Lower Siniy Gai A, southern Primorye (Museum of Archaeology and Ethnography of Far Eastern Federal University); 7-8, Zaisanovskaya, Valentin Peresheek, southern part of Primorye (Institute of History, Archaeology and Ethnography of Peoples of Far East); 9, Early Chulmun, Osan-li, Korea (Chuncheon National Museum); 10, Middle Chulmun, Hasidong, Korea (Chuncheon National Museum); 11, Late Chulmun, Bangokdong, Korea (Chuncheon National Museum); 12, Late Chulmun, Wonsudae, Korea (National Museum of Korea). (b) Disk-like whorls: 13, Xinglongwa (Schelach and Teng 2013, p. 44); 14, Zhaobaogou; Aohan Banner (Aohan Zhaobaogou, Xinshiqi Shidai Juluo 1997, Fig. 35); 15, Hongshan, Wengniute Banner, Inner Mongolia (http://blog.sina.cn); 16, Zaisanovka, Lower Siny Gai A, southern part of Primorye (Museum of Archaeology and Ethnography of Far Eastern Federal University); 17, Early-Middle Chulmun, Amsadong, Seoul (National Museum of Korea); 18, Yayoi, Shimonagata B, Japan; 19, Yayoi, Karako-Kagi (http://www.town.tawaramoto.nara.jp/ karako_kagi/museum/syoukai/search/2/yayoinowaza/oruamuwaza/oruwaza/bosuisha/7569.html). (c) Loom weights: 20, Xinglongwa (Wu and Liu 2003); 21, Hongshan, Wengniute Banner, Inner Mongolia (http://blog.sina.cn); 22-23, Zaisanovskaya, Lower Siniy Gai A, southern part of Primorye (Museum of Archaeology and Ethnography of Far Eastern Federal University). 
In sum, there appear to be significant similarities between (bi)conical spindle whorls, disk-like whorls and loom weights across different regions of Northeast Asia at different times in the Neolithic and Bronze Age.

In addition, there is an interesting contrast in the distribution of (bi)conical whorls as opposed to disk-like whorls. There is a strong concentration of disk-like whorls in the Xinglongwa and Zhaobagou cultures of the West Liao River Basin and they are exclusively found in the Xiaozhushan and Houwa cultures of the Liaodong Peninsula (Furusawa 2007, p. 100) and in Yayoi Japan. They are also more frequent than (bi)conical whorls in Neolithic sites of the western and southeastern part of the Korean Peninsula (Choi 2011). In contrast, the Xinglongwa and Hongshan cultures of the West Liao River Basin yield biconical whorls at a few sites, such as the Baiyinchanghan II and Jiefangyingzi sites in Wengniute Banner. For the sites of Niuheliang and Weijiapou a question mark is inserted with disklike whorls because the site reports mention spindle whorls without picture or specification of their being disk-like or (bi)conical. However, as (bi)conical whorls seem to be the exception rather than the norm here, we would expect excavators to make mention of (bi)conical shapes. Interestingly, the Upper Xinle site in the Lower Liao River Basin, the Yinggelin site on the Amur River and the Zaisanovka culture of the southern part of the Primorye region display (bi)conical spindle whorls. They are also more numerous than disk-like whorls in the northeastern and mid-eastern part of the Korean Peninsula (Choi 2011, Nelson 1993, pp. 100, 160). This observation hints at two geographically and chronologically different routes for the dispersal of textile technology out of the Liao River region, indicated in red and blue in Figure 4.

\section{Prediction 3: Neolithic/ Bronze Age cultures with evidence for spindle whorls tend to have evidence for agriculture}

This prediction can be confirmed. The majority of sites with evidence for spindle whorls in Table 1 score positive for the attestation of millet cultivation or agricultural tools. Four sites in Northeast China lack direct evidence of millet cultivation but they all have indirect evidence of agriculture such as stone hoes and axes.

Unfortunately, the Valentin-Peresheek and Siny Gai sites from the Russian Far East were excavated in the 1960s and 1970s, when soil flotation for detecting of plant remains was not yet applied. Therefore, we do not have any archaeobotanical evidence for millet or hemp cultivation from these sites, but the Zaisanovka culture to which these sites belong is known as the first farming culture in the Russian Far East. Carbonized millet grains have been found at the Bogolyubovka-1 site and at the upper Zaisanovka horizon of the Sheklyaevo-7 site (Leipe et al. 2019). In addition, the Siny Gai A and Bogolyubovka-1 sites yield stone constricted hoes, grinding slabs and grinders, suggesting agriculture. At the Valentin-Peresheek site a series of rough hoes and small-sized grinding slabs with grinders were excavated, but analysis shows that these were used for crushing of the mineral pigment ocher. It is unclear whether they were used for agricultural purposes as well. However, the Valentin-Peresheek area, which is located at the seacoast, offers less favorable conditions for agriculture than the Siny Gai area, located close to Lake Khanka in the southwestern part of the Primorye.

While the early site of Amsadong has provided most of the inferences about food production in the Early Neolithic of Korea, charred foxtail millet seeds have been systematically identified at Pibong-li as well (Lee and Kwak 2019). Osan-li depended heavily on fishing, and acorn remains along with pestles and mortars show that this was supplemented by gathering wild plants, but there is no evidence of millet cultivation (Ahn et al. 2015). Some Middle to Late Chulmun sites such as Sŏp'ohang, Nongpodong and Sinam-li lack direct evidence for millet cultivation, but agricultural tools have been discovered at these sites. Whereas the Kungsan-li site yields small amounts of unidentified grains, the Tongsamdong site has direct evidence for foxtail and broomcorn millet agriculture (Lee 2011). Flotation of Late Chulmun sites such as Jungsandong has yielded foxtail and broomcorn millet seeds (Kim et al. 2015). In general, all Korean Neolithic sites in the table yield various tools related to food production but it is hard to define them as exclusively agricultural tools. Half-moon-shape 


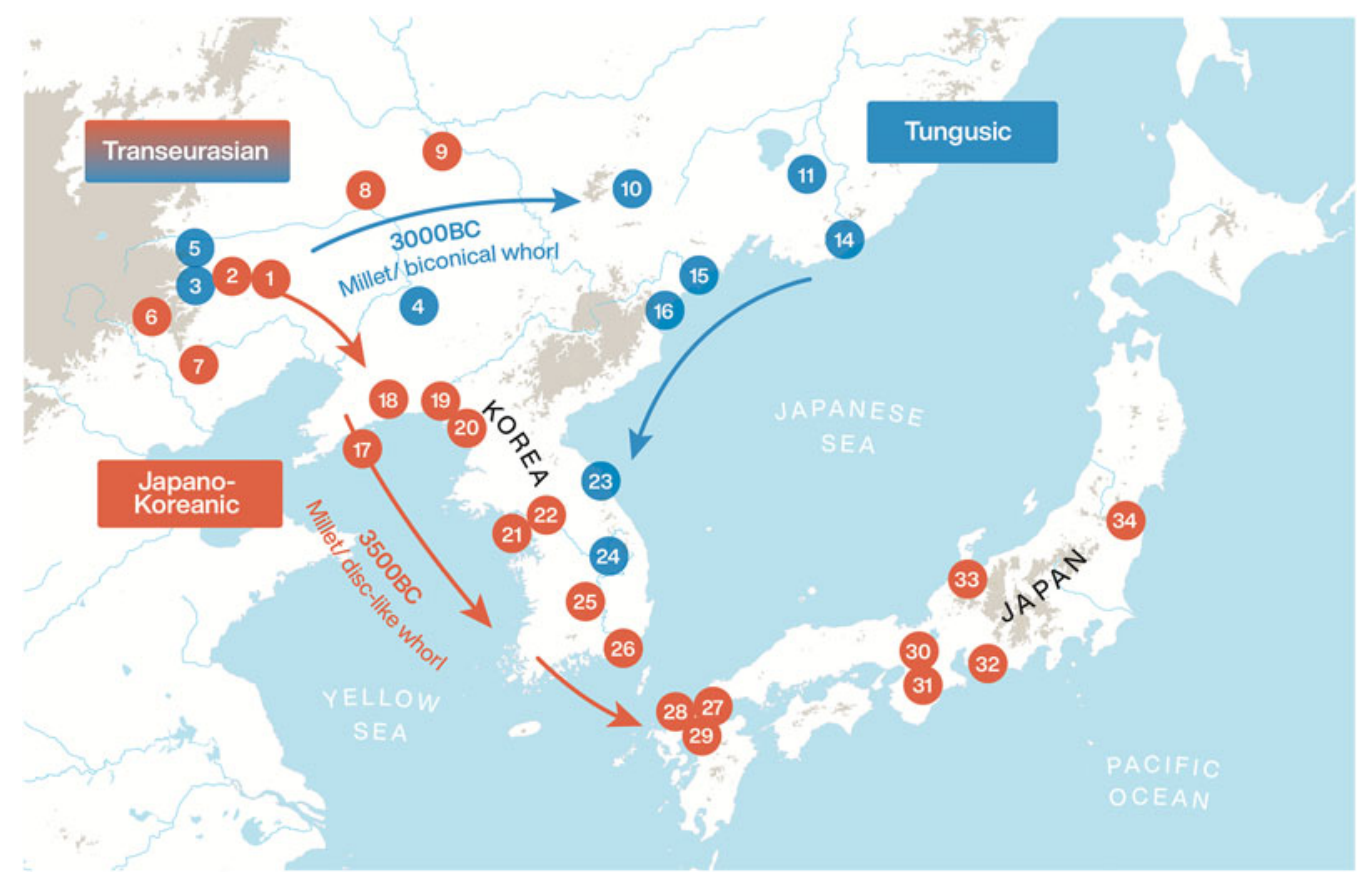

Figure 4. The dispersal of textile technology, agriculture and language across Northeast Asia. The numbers correspond to the sites, listed in Figure 2. Archaeological sites where (bi)conical whorls have been recovered in relatively high proportions are indicated in blue.

sickles, for instance, were probably used for harvesting, but could have been used for collecting wild edible plants too.

Cultivated plant remains were identified at only a few of the Japanese sites examined here, but this can be explained by the lack of systematic archaeobotanical investigations at those sites. There is no question that many of the sites from Japan with evidence of weaving and textile production are well known as important Yayoi period settlements with evidence for agriculture and for continental cultural traits such as rice paddy fields, defensive moats and palisades, wooden and stone farming tools, early bronze and iron, and carp aquaculture (Hudson 1990; Nakajima et al. 2019). At Yoshinogari (Saga), for example, at least six spindle whorls and 11 pieces of cloth made from both hemp and silk have been found (Shichida 2005; Hudson and Barnes 1991). Yoshinogari has also produced extensive evidence of an agricultural economy including reaping knives, forks and spades, mortars and pestles, and a series of large buildings which are reasonably interpreted as storehouses. Phytoliths of rice and barley have been identified at Yoshinogari but the archaeobotany of the site remains poorly understood. However, this does not mean that the inhabitants of the site did not practice farming.

\section{Discussion}

Whereas pre-agricultural societies such as the Boisman (4825-2470 BCE) in the Russian Far East, the Incipient Chulmun (8000-6000 BCE) populations on the Korean Peninsula and the Jomon (10000$900 \mathrm{BCE}$ ) in Japan showed no evidence for weaving, spindle whorls appear with the transition to agriculture. We find the earliest evidence for spinning in Northeast China within the context of the Xinglongwa and Zhaobagou cultures in the West Liao River Basin. Subsequently, we find evidence for textile technology more sophisticated than sewing tools, starting from Zaisanovka times in the Russian Far East, Early Chulmun times on the Korean peninsula and Yayoi times in Japan. All of these cultures are associated with the beginning of agriculture in the respective regions. 
The transition to sophisticated textile technology seems to mirror the transition to agriculture in time and space: around 3000 BCE millet agriculture was transmitted from the Hongshan culture in the West Liao River Region to the southern part of the Primorye (Li et al. 2020), while conical spindle whorls, disk-like whorls and loom weights similar to those of the Hongshan culture arrived in the southern part of the Primorye around the same time in the context of the same Zaisanovka culture. This route is indicated in blue on the map in Figure 4. Around 4000 BCE millet agriculture was transmitted from the Hongshan culture to the cultures on the Liaodong Peninsula (Xu 1995) and subsequently, around $3500 \mathrm{BCE}$, to the Korean Peninsula (Lee 2011). From there, an integrated agricultural package including millet and rice was further transferred to Japan in 900 BCE. Disk-like whorls and loom weights recalling those of the Xinglongwa culture appear around the same time as millet agriculture in the same sites on Liaodong, the Korean Peninsula and Japan. This route is indicated in red on the map in Figure 4.

Interestingly, the red and blue dispersal routes on the map also have a linguistic correlate: the ancestral proto-Transeurasian language has its homeland in the West Liao River region, the Japano-Koreanic branch separated from the Altaic unity around $4700 \mathrm{BCE}$ and settled on the Liaodong Peninsula and the separation and dispersal of Koreanic and Japonic to their present-day locations followed in the ensuing millennia. The time and space of these linguistic dispersals mirror those of millet agriculture with disk-like whorls. in contrast, the Tungusic branch separated around $3300 \mathrm{BCE}$ and moved from the West Liao River region to the southern part of the Primorye, mirroring the dispersal of millet agriculture with conical whorls.

As far as Transeurasian prehistory is concerned, we traced population movements in North and East Asia through the linguistics and archaeology of textile production. We found that the area West of the Liao River in Northeast China was a Neolithic center of diffusion, not only of millet agriculture, but also of words and tools for spinning and weaving. As such, we provided additional support for the Language/Farming Dispersal Hypothesis of the Transeurasian languages.

From a theoretical viewpoint, our study may have some broader implications for debates surrounding the Language/Farming Dispersal Hypothesis. By focusing on industries like textile production rather than just food production, we viewed the spread of agriculture as an interconnected assemblage of ideas, practices and technologies that travel together rather than as a mere collection of crops and tools associated with plant cultivation. From this perspective, the spread of textile technology becomes useful as a marker of agricultural dispersal and population migration. In line with Tehrani et al.'s (2010) assumption that the history of weaving traditions is strongly correlated with population histories and with Buckley's (2012) findings about the associated spread of Austronesian language with Neolithic weaving and farming technologies, our results show that parallels exist between the dispersal patterns of Neolithic technologies such as textile production and agriculture and the spread of the Transeurasian languages across Northeast Asia.

Supplementary material. Supplementary Table S1 shows the reconstruction of textile vocabulary to proto-Transeurasian and daughter branches based on linguistic comparison of the Transeurasian languages in addition to a detailed historical comparative linguistic dataset of Transeurasian cognates underlying our analysis. Supplementary Table S2 shows the association between language families and archaeological cultures. The supplementary material for this article can be found at https://doi.org/10.1017/ehs.2020.4.

Acknowledgements. We would like to thank Director Bae Kidong and Associate Curator Yoon Jiyeon of the National Museum of Korea for providing us with pictures and information on spindle whorls. We further acknowledge the Museum of Archaeology and Ethnography of the Far Eastern Federal University and the Institute of History, Archaeology and Ethnography of Peoples of the Far East for granting us permission to make and use pictures of items in their collections. We are also grateful to Thierry Bogaert for his advice and information with regard to textile technology and iconography and to Ian Joo for his help in translating a Korean publication.

Author contributions. M.R. and S.N. conceived and designed the study. I.Z., T.L., M.H., S.N. and M.R. conducted data gathering. M.R. performed comparative analyses. M.R. and S.N. wrote the article. 
Financial support. The research leading to these results has received funding from the European Research Council under the European Union's Horizon 2020 research and innovation programme (grant agreement no. 646612) granted to Martine Robbeets.

Conflicts of interest. Authors declare none.

Data availability statement. All data and material underlying our research are referenced in the article or made available in the Supplementary Material.

\section{References}

Ahn SM, Kim J and Hwang J (2015) Sedentism, settlements, and radiocarbon dates of Neolithic Korea. Asian Perspectives 54 (1), 113-143.

Aikhenvald A (1999) The Arawak language family. In A Aikhenvald and R Dixon (eds), Amazonian languages (pp. 65-106). Cambridge: Cambridge University Press.

An Z (1955) Zhongguo gudai de shidao. [Stone knives in ancient China.] Acta Archaeologica Sinica 10, 27-51.

Andreeva ZV (ed) (1987) Valentin-peresheek - poselok drevnih rudokopov. [Valentin-Peresheek site as a settlement of old miners.] Moscow: Nauka.

Anthony DW (2007) The Horse, the Wheel, and Language: how Bronze-Age Riders from the Eurasian Steppes Shaped the Modern World. Princeton, NJ: Princeton University Press.

Bellwood P (1984) The great Pacific migration. Encyclopaedia Britannica Yearbook of Science and the Future 1984, 80-93.

Bellwood P (2005) First Farmers: the Origins of Agricultural Societies. Malden, MA: Blackwell.

Bellwood P (2011) First Migrants: Ancient Migration in Global Perspective. Malden, MA: Blackwell.

Bellwood P and Renfrew C (eds) (2002) Examining the Farming/Language Dispersal Hypothesis. Cambridge: McDonald Institute for Archaeological Research.

Blust R (1995) The prehistory of the Austronesian-speaking peoples: a view from language. Journal of World Prehistory $\mathbf{9}$, 453-510.

Blust R (2013) The Austronesian Languages. Asia-Pacific Linguistics. Open access monographs. Canberra: Australian National University.

Bostoen K and Koni Muluwa J (2017) Were the first Bantu speakers south of the rainforest farmers? A first assessment of the linguistic evidence. In M Robbeets and A Savelyev (eds), Language dispersal beyond farming (pp. 235-258). Amsterdam: Benjamins.

Brodyansky DL (2013) Siny Gai: poseleinya neolita I bronzovogo veka v Primor'e. [Siny Gai: The Settlements of the Neolithic and Bronze Age in Primorye.] Vladivistok: Far Eastern Federal University Press.

Brown C (2015) Paleobiolinguistics of New World crops and the Otomanguean language family. Ethnobiology Letters 6(1), 189-191.

Buckley C (2012) Investigating cultural evolution using phylogenetic analysis: the origins and descent of the Southeast Asian tradition of warp Ikat weaving. PLoS ONE 7(12): e52064. https://doi.org/10.1371/journal.pone.0052064

Campbell L (2004 [1998]) Historical Linguistics: an Introduction. Edingburgh: Edingburgh University Press.

Chang K-C (1986) The Archaeology of Ancient China. New Haven, CT: Yale University Press.

Childs-Johnson E (2001) Enduring Art of Jade Age China: Chinese Jades of Late Neolithic to Han periods. New York: Throckmorton Fine Art.

Choi H (1985) Hanbando c'ult'o pangc'uc'a-ey kwanhan yŏngu. [A study on excavated spindle wheels on the Korean peninsula.] Cŏngshin Munhwa [Spiritual Culture] 25. Seoul: Korean Spiritual Culture Research Institute.

Choi D-J (2011) Study on spindle wheel to the Korean peninsula in the Neolithic era. Journal of the Korean Neolithic Society 21, 103-127.

Clarke RC (2006) Hemp (cannabis) cultivation and use in the Republic of Korea. Journal of Industrial Hemp 11(1), 51-86.

Comrie B (2002) Farming dispersal in Europe and the spread of the Indo-European language family. In P Bellwood and C Renfrew (eds), Examining the Language/Farming Dispersal Hypothesis (pp. 409-420). Cambridge: McDonald Institute for Archaeological Research.

Cort LA (1989) The changing fortunes of three archaic Japanese textiles. In AB Weiner and J Schneider (eds), Cloth and Human Experience (pp. 377-414). Washington, DC: Wenner-Gren Foundation.

Crawford GW (2006) East Asian plant domestication. In MT Stark (ed.), Archaeology of Asia (pp. 77-95). Blackwell: Oxford.

Diamond J and Bellwood P (2003) Farmers and their languages: the first expansions. Science 300, 597-603.

Dybo A and Starostin G (2008) In defense of the comparative method, or the end of the Vovin controversy. Aspects of Comparative Linguistics 3, 119-258.

Epps P (2015) Historical linguistics and socio-cultural reconstruction. In C Bowern and B Evans (eds), The Routledge Handbook of Historical Linguistics (pp. 579-597). London: Routledge.

Fujimura J (1985) Bōsuisha. [Spindle whorls.] In H Kanaseki and M Sahara (eds), Yayoi bunka no kenkyū. [Research on Yayoi Culture.] (Vol. 5, pp. 173-177). Tokyo: Yūzankaku. 
Furusawa Y (2007) A study on the environmental change and adaptation system in prehistoric Northeast Asia. In M Komoto (ed.), Tōhoku Ajia no kankyō henka to nariwai shistemu [Northeast Asia's enviromental change and subsistence systems] (pp. 86-109). Kumamoto: Kumamoto University.

Gamkrelidze TV and Ivanov VV (1995) Indo-European and the Indo-Europeans. A Reconstruction and Historical Analysis of a Proto-language and Proto-culture. Part I: The Text. Part II: Bibliography, indexes. Translated by Johanna Nichols. Berlin: de Gruyter Mouton.

Garkovik AV and Sergusheva EA (2014) Bogolyubovka-1 - poselenie rannih zemledel'tsev Primor'ya. [Bogolyubovka-1 Settlement of Old Farmers of Primorye.] Gumanitarnye issledovanoya $v$ Vostochnoi Sibiri I na Dal'nem Vostoke [Humanities Research in the Russian Far East] 4, 34-44.

Hudson MJ (1990) From Toro to Yoshinogari: changing perspectives on Yayoi period archeology. In G Barnes (ed.), Hoabinhian, Jomon, Yayoi, Early Korean States: Bibliographic Reviews of Far Eastern Archaeology (pp. 63-111). Oxford: Oxbow.

Hudson MJ and Barnes G (1991) Yoshinogari: a Yayoi settlement in north Kyushu. Monumenta Nipponica 46, $211-235$.

Hyland DC, Zhushchikhovskaya IS, Medvedev VE, Derevianko AP and Tabarev AV (2002) Pleistocene textiles in the Russian Far East: impressions from some of the world's oldest pottery. Anthropology 40(1), 1-10.

Iversen R and Kroonen G (2017) Talking Neolithic: linguistic and archaeological perspectives on how Indo-European was implemented in southern Scandinavia. American Journal of Archaeology 121(4), 511-525.

Johanson L (2010) The high and low spirits of Transeurasian language studies. In L Johanson and M Robbeets (eds), Transeurasian Verbal Morphology in a Comparative Perspective: Genealogy, Contact, Chance. Turcologica 78. Wiesbaden: Harrassowitz.

Kaner S (2009) Long-term innovation: appearance and spread of pottery in the Japanese archipelago. In P Jordan and M Zvelebil (eds), Ceramics Before Farming: The Dispersal of Pottery Among Prehistoric Eurasian Hunter-Gatherers (pp. 93-119). Walnut Creek CA: Left Coast Press.

Kaufman T (1990) Early Otomanguean homelands and cultures: some premature hypotheses. University of Pittsburgh Working Papers in Linguistics 1, 91-136.

Kawashima T (2016) Food processing and consumption in the Jomon. Quaternary International 404, 16-24.

Kent KP and Nelson SM (1976) Net sinkers or weft weights? Current Anthropology 17(11), 152.

Kim J (1978) The Prehistory of Korea. Translated and edited by R Pearson and K Pearson. Honolulu, HI: University of Hawaii Press.

Kim M, Shin H, Kim S, Lim D, Jo K, Ryu A, Won H, Oh S and Noh H (2015) Population and social aggregation in the Neolithic Chulmun villages of Korea. Journal of Anthropological Archaeology 40, 160-182.

Kimhae National Museum (2018) Report on the Research of Antiquities, Vol. 6, Bibongni, Changnyeong. Kimhae: National Museum Press.

Kluyev NA, OV Yanshina and NA Kononenko (2003) Poselenie Sheklyaevo-7 - novy neoliticheskii pamyatnik v Primor'e. [Sheklyaevo-7 settlement as a new Neolithic site in the Primorye.] Rossiya i ATR 4, 5-15.

Kroonen G (2012) Non-Indo-European root nouns in Germanic: evidence in support of the Agricultural Substrate Hypothesis. In R Grünthal and P Kallio (eds), A linguistic map of prehistoric Northern Europe (pp. 239-260). Helsinki: Suomalais-Ugrilainen Seura.

Kudo Y and Hitoki E (2014) Compilation of evidences of Cannabis sativa in the Jomon period. Kokuritsu Rekishi Minzoku Hakubutsukan Kenkyuu Houkoku 187, 425-440.

Kümmel M (2017) Agricultural terms in Indo-Iranian. In M Robbeets and A Savelyev (eds), Language Dispersal Beyond Farming (pp. 275-290). Amsterdam: Benjamins.

Kuzmin YV, Charles TK, Timothy Jull AJ, Burr GS and Klyuev NA (2012) The earliest surviving textiles in East Asia from Chertovy Vorota Cave, Primorye Province, Russian Far East. Antiquity 86, 325-337.

Lee G (2011) The transition from foraging to farming in prehistoric Korea. Current Anthropology 52, 307-329.

Lee R (2019) Gendered spaces and prehistoric households: a geospatial analysis of Mumun period pithouses from South Korea. Asian Perspectives 58, 74-94.

Lee $\mathbf{G}$ and Kwak $\mathbf{S}$ (in press) Broad-spectrum foodways in coastal Korea during the Middle Holocene: isotopic and archaeobotanical signatures in Neolithic shell middens. Vegetation History and Archaeobotany.

Leipe C, Long T, Sergusheva EA, Wagner M and Tarasov PE (2019) Discontinuous spread of millet agriculture in eastern Asia and prehistoric population dynamics. Science Advances 5, eaax6225.

Levitskaya LS (1997a) Material'naja kul'tura: Izgotovlenije vojloka. [Material culture: Felt production.] In ER Tenišev (ed.), Sravnitel'no-istoričeskaja grammatika tjurkskix jazykov. Leksika [A Historical Comparative Grammar of the Turkic Languages. Lexicon] (pp. 392-394). Moscow: Nauka.

Levitskaya LS (1997b) Material'naja kul'tura: Pletenije, tkačestvo. [Material Culture: Weaving.] In ER Tenišev (ed.), Sravnitel'no-istoričeskaja grammatika tjurkskix jazykov. Leksika [A Historical Comparative Grammar of the Turkic Languages. Lexicon] (pp. 394-397). Moscow: Nauka.

Levitskaya LS (1997c) Material'naja kul'tura: Odežda, obuv', golovnyje ubory. [Material culture: Clothing. Footwear. Headgear.] In ER Tenišev (ed.), Sravnitel'no-istoričeskaja grammatika tjurkskix jazykov. Leksika [A Historical Comparative Grammar of the Turkic Languages. Lexicon] (pp. 472-485). Moscow: Nauka. 
Li T, Robbeets M, Ning C, Zhushchikhovskaya I and Hudson M (2020) Millet agriculture dispersed from Northeast China to the Russian Far East: Integrating archaeology, genetics, and linguistics. Archaeological Research in Asia, in press.

Long T, Wagner M, Demske D, Leipe C and Tarasov PE (2017) Cannabis in Eurasia: origin of human use and Bronze Age trans-continental connections. Veget Hist Archaeobot 26, 245-258. doi: 10.1007/s00334-016-0579-6

Matsuura I (2017) The emergence of pottery and the establishment of Jomon pottery on the Japanese Archipelago. Emergence of Neolithic Culture and Preservation of Prehistoric Sites. Amsadong Site Research Series 1, 57-84.

Mayrhofer M (1992-2001) Etymologisches Wörterbuch des Altindoarischen. Heidelberg: Winter.

Nagasaki M (1978) Jōmon no bōsuisha. [Jomon spindle whorls.] Naganoken Kōkogaku Kaishi 32, 1-18.

Nakajima T, Hudson MJ, Uchiyama J, Makibayashi K and Zhang J (2019) Common carp aquaculture in Neolithic China dates back 8000 years. Nature Ecology and Evolution. doi: 10.1038/s41559-019-0974-3

Nelson SM (1975) The subsistence base of Middle Han Sites of the Chulmun period. Asian Perspectives 18(1), 5-14.

Nelson SM (1993) The archaeology of Korea. Cambridge: Cambridge University Press.

Nelson SM (2017) The Amsa Neolithic Site and the beginning of plant cultivation. Emergence of Neolithic Culture and Preservation of Prehistoric Sites. Amsadong Site Research Series 1, 10-22.

Noshiro S and Sasaki Y (2014) Pre-agricultural management of plant resources during the Jomon period in Japan - a sophisticated subsistence system on plant resources. Journal of Archaeological Science 42, 93-106.

Nunome J (1985) Asa to kinu. [Hemp and silk.] In H Kanaseki and M Sahara (eds), Yayoi bunka no kenkyū [Research on Yayoi Culture] (Vol. 5, pp. 184-188). Tokyo: Yūzankaku.

Nunome J (1995) Wajin to kinu: Yayoi jidai no orimono bunka. [Wajin and silk: the weaving culture of the Yayoi period.] Tokyo: Shōgakukan.

Omura M and Kizawa N (2017) The textile terminology in ancient Japan. In S Gaspa, C Michel and M-L Nosch (eds), Textile Terminologies from the Orient to the Mediterranean and Europe, 1000 BC to 1000 AD (pp. 451-482). Lincoln, NE: Zea Books. doi: 10.13014/K2RN361H

Ozeki K (2018) Jömon no nuno: Nihon rettō Nuno bunka no kigen to tokushitsu. [Jomon cloth: the origins and characteristics of textile culture in the Japanese archipelago.] Revised edition. Tokyo: Takeuchi Shoten.

Pawley A (2002) The Austronesian dispersal: languages, technologies and people. In P Bellwod and C Renfrew (eds), Examining the Language/Farming Dispersal Hypothesis (pp. 251-274). Cambridge: McDonald Institute for Archaeological Research.

Philipson D (2002) Language and farming dispersals in sub-Saharan Africa, with particular reference to the Bantu-speaking peoples. In P Bellwood and C Renfrew (eds), Examining the Language/Farming Dispersal Hypothesis (pp. 177-190). Cambridge: McDonald Institute for Archaeological Research.

Pictet A (1859) Les origines indo-européennes ou les aryas primitifs: essai de paléontologie linguistique (première partie, seconde partie). Paris: Joël Cherbuliez.

Renfrew C (1987) Archaeology and Language: The Puzzle of Indo-European Origin. London: Jonathan Cape.

Robbeets M (2005) Is Japanese Related to Korean, Tungusic, Mongolic and Turkic? (Turcologica 64.) Wiesbaden: Harrassowitz.

Robbeets M (2015) Diachrony of Verb Morphology: Japanese and the Transeurasian Languages. Trends in Linguistics Studies and Monographs 291. Berlin: Mouton-De Gruyter.

Robbeets M (2017) The language of the Transeurasian farmers. In M Robbeets and A Savelyev (eds), Language Dispersal Beyond Farming (pp. 93-116). Amsterdam: Benjamins.

Robbeets M (2020a) The Transeurasian homeland: where, what and when? In M Robbeets, N Hübler and A Savelyev (eds), The Oxford Guide to the Transeurasian Languages. Oxford: Oxford University Press.

Robbeets M (2020c) Basic vocabulary in Transeurasian. In M Robbeets, N Hübler and A Savelyev (eds), The Oxford Guide to the Transeurasian Languages. Oxford: Oxford University Press.

Robbeets M and Bouckaert R (2018) Bayesian phylolinguistics reveals the internal structure of the Transeurasian family. Journal of Linguistic Evolution 3, 145-162.

Robbeets M and Savelyev A (eds) (2017) Language Dispersal Beyond Farming. Amsterdam: Benjamins.

Robbeets M (2020b) Verbal morphology in Transeurasian. In M Robbeets, N Hübler and A Savelyev (eds), The Oxford Guide to the Transeurasian Languages. Oxford: Oxford University Press.

Russo EB (2007) History of cannabis and its preparations in saga, science, and sobriquet. Chemistry and Biodiversity 4, 16141648.

Sagart L, Jacques G, Lai Y, Ryder RJ, Thouzeau V, Greenhill SJ and List J-M (2019) Dated language phylogenies shed light on the ancestry of Sino-Tibetan. Proceedings of the National Academy of Sciences. doi: 10.1073/pnas.1817972116

Schapper A (2017) Farming and the Trans-New Guinea family: a first consideration. In M Robbeets and A Savelyev (eds), Language Dispersal Beyond Farming (pp. 155-181). Amsterdam: Benjamins.

Schelach G and Teng M (2013) Earlier Neolithic economic and social systems of the Liao River Region, Northeast China. In AP Underhill (ed.), A Companion to Chinese Archaeology (pp. 35-54). London: Blackwell.

Sergusheva EA (2013) Dinamika zemledeliya v pozdnem neolite Primor'ya po dannym arheobotaniki. [Dynamics of agriculture in the Late Neolithic in the Primorye based on the data of archeobotany.] Vestnik arheologii, antropologii $i$ etnografii [Bulletin of Archaeology, Anthropology and Ethnography] 4(23), 155-162. 
Shichida T (2005) Yoshinogari iseki: fukugen sareta Yayoi daishūraku. [The Yoshinogari site: reconstructing a large Yayoi settlement.] Tokyo: Dōseisha.

Shimunek A (2017) An Old Chinese Word for 'silk' in Mongolic, Turkic, Tungusic, and Persian. Eurasian Studies 15(1), 142-151.

Sidwell P and Blench R (2011) The Austroasiatic Urheimat: the Southeastern Riverine Hypothesis. In N Enfield (ed.), Dynamics of Human Diversity: the Case of Mainland Southeast Asia (pp. 315-343). Canberra: Pacific Linguistics.

Starostin S, Dybo A and Mudrak O (2003) Etymological Dictionary of the Altaic Languages. Leiden: Brill.

Takeuchi A (1985) Shokki [Looms]. In H Kanaseki and M Sahara (eds), Yayoi bunka no kenkyū [Research on Yayoi Culture] (Vol. 5, pp. 178-183). Tokyo: Yūzankaku.

Tehrani J, Collard M and Shennan S (2010) The cophylogeny of populations and cultures: Reconstructing the evolution of Iranian tribal craft traditions using trees and jungles. Philosophical Transactions of the Royal Society B 365, 3865-3874. doi:10.1098/rstb.2010.0020

Van Driem G (2017) The domestications and the domesticators of Asian rice. In M Robbeets and A Savelyev (eds), Language Dispersal Beyond Farming (pp. 183-214). Amsterdam: Benjamins.

Vovin A (2005) The end of the Altaic controversy. Central Asiatic Journal 49, 71-132.

Wu X (2004) Female and male status displayed at the Maoqinggou cemetery. In KM Linduff and S Yan (eds), Gender and Chinese Archaeology (pp. 203-235). Walnut Creek: AltaMira Press.

Wu J (2007) The Late Neolithic cemetery at Dadianzi, Inner Mongolia Autonomous Region. In KM Linduff and K Rubinson (eds), Gender and Chinese Archaeology (pp. 47-94). Walnut Creek: AltaMira Press.

Wu CY and Liu YW (2003) Xinshiqi shidai de Xinglongwa wenhua. [A Discussion about Xinglongwa Culture in the Neolithic Age.] Tangshan Shifan Xueyuan Xuebao [Journal of Tangshan Teachers College] 25(3), 55-57.

Xu Y (1995) The Houwa site and related issues. In SM Nelson (ed.), The Archaeology of Northeast China (pp. 65-88). London: Routledge.

Zhushchikhovskaya IS (2006) Neolithic of the Primorye. In SM Nelson, AP Derevianko, YaV Kuzmin and RL Bland (eds), Archaeology of the Russian Far East: Essays in Stone Age Prehistory (pp. 101-122). Oxford: British Archaeological Reports.

Cite this article: Nelson S, Zhushchikhovskaya I, Li T, Hudson M, Robbeets M (2020). Tracing population movements in ancient East Asia through the linguistics and archaeology of textile production. Evolutionary Human Sciences 2, e5, 1-20. https://doi.org/10.1017/ehs.2020.4 